\title{
PENGEMBANGAN SISTEM PELATIHAN JARAK JAUH BERBASIS MOODLE DI BALAI DIKLAT KEAGAMAAN BANDUNG
}

\author{
Firman Nugraha ${ }^{1}$, Dedi Restendi ${ }^{2}$, Agus Triyanto ${ }^{3}$ \\ ${ }^{1}$ Balai Diklat Keagamaan Bandung, Badan Litbang dan Diklat Kementerian Agama \\ ${ }^{2}$ Balai Diklat Keagamaan Bandung, Badan Litbang dan Diklat Kementerian Agama \\ ${ }^{3}$ Balai Diklat Keagamaan Bandung, Badan Litbang dan Diklat Kementerian Agama \\ ${ }^{1}$ firmannugraha@kemenag.go.id, 2restendidedi@gmail.com, ${ }^{3}$ apayamasa@yahoo.co.id
}

https://doi.org/10.36052/andragogi.v8i2.166

Diterima: 08 September 2020 | Disetujui: 20 Desember 2020 | Dipublikasikan: 26 Desember 2020

\begin{abstract}
Abstrak
Pengembangan sistem pelatihan online diperlukan untuk menciptakan pemerataan kesempatan mengikuti pelatihan, memperkaya materi pembelajaran, dan meningkatkan partisipasi peserta pelatihan dalam pembelajaran. Pengembangan ini juga menjadi media untuk menciptakan lingkungan pembelajaran yang mudah diakses. Pelatihan online memerlukan learning management system. Salah satu aplikasi yang banyak digunakan adalah moodle. Saat ini telah hadir versi terbaru dalam moodle yang dapat digunakan untuk peningkatan mutu pelatihan online yaitu moodle versi 3.8.0. Tujuan penelitian ini adalah untuk mengetahui implementasi sistem pelatihan jarak jauh berbasis moodle versi tersebut pada Balai Diklat Keagamaan Bandung Tahun 2020. Jenis penelitian yang diterapkan adalah Penelitian dan Pengembangan model waterfall. Pengujian aplikasi dengan teknik blackbox. Sedangkan analisis menggunakan SCORM dan Haughey teori. Hasil penelitian menunjukkan bahwa website pelatihan jarak jauh berbasis moodle dapat dikatakan baik berdasarkan uji black box. Hal tersebut dapat dilihat dari beberapa aspek seperti tampilan dan isi website, pelaksanaannya, kesiapan kelembagaan, serta sarana dan prasarana. Website pelatihan jarak jauh berbasis moodle 3.8.0 disarankan untuk disosialisasikan dan disediakan petunjuk manual pelatihan jarak jauh.
\end{abstract}

Kata Kunci: pelatihan jarak jauh, moodle,

\begin{abstract}
[MOODLE BASED DISTANCE TRAINING SYSTEM DEVELOPMENT IN BALAI DIKLAT KEAGAMAAN BANDUNG]. Developing online training system is essential to create equalization over training opportunities, enrich learning materials, and increase trainees participation in learning. The development is also a medium to create accessible learning environment. Online training requires learning management system. One of the most widely used applications is Moodle. It has the latest version that can be used to improve online training's quality, namely Moodle version 3.8.0. This study aims to find out Moodle-based remote training system implementation at Bandung Religious Training Center in 2020. Research and Development waterfall model is applied. Application testing is by using blackbox techniques. The analysis uses SCORM and Haughey theory. The result showed that Moodle-based remote training is considered good based on black box tests. It can be seen from several aspects of websites, such as appearance and content, implementation, institutional readiness, as well as facilities and infrastructure. Moodle 3.8.0 based remote training websites are recommended for socialization and provided remote training manual instructions.
\end{abstract}

Keywords: distance training, moodle

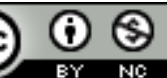

This work is licensed under a Creative Commons Attribution-NonCommercial 4.0 International License 


\section{PENDAHULUAN}

P esatnya perkembangan internet bagi Balai Diklat Keagamaan Bandung yang merupakan unit pelaksana teknis di bidang pelatihan dan pengembangan kompetensi aparatur sipil Negara (ASN) menjadi jalan keluar atas permasalahan klasik yang dihadapi. Persoalan-persoalan itu seperti keterbatasan anggaran penyelenggaraan pelatihan, belum meratanya kesempatan memperoleh pelatihan dan letak geografis domisili ASN yang ditugaskan pada satuan kerja yang berada jauh di pelosok daerah. Internet memungkinkan tersedianya layanan pelatihan yang dilaksanakan melalui e-learning melalui penyediaan bahan pelatihan secara daring yang dapat diakses oleh para pegawai yang membutuhkan.

Sejalan dengan kebutuhan terhadap metode dan konsep pembelajaran dalam pelatihan yang lebih efektif dan efisien, maka penggunaan teknologi informasi untuk pelatihan menjadi niscaya. Konsep yang kemudian dikenal dengan istilah e-learning ini berdampak pada terjadinya proses transformasi pendidikan dari konvensional ke dalam bentuk digital, baik dalam substansi maupun sistem. Seperti yang diungkapkan oleh Darin E. Hartley (Hartley, 2001) yang mengatakan bahwa elearning adalah suatu jenis belajar mengajar yang memungkinkan tersampaikannya bahan ajar ke siswa dengan menggunakan media Internet, Intranet atau media jaringan komputer lain. Berkenaan dengan hal itu, seperti sekarang dapat disaksikan, konsep elearning sudah banyak diterima oleh masyarakat dunia, terbukti dengan maraknya implementasi e-learning di lembaga pendidikan (Al-araibi, A. A. M., Naz'ri bin Mahrin, M., Yusoff, R. C. M., \& Chuprat, 2019) maupun industri (Chang, 2016; Tvenge, N., \& Martinsen, 2018).

E-learning ini pada umumnya dengan bantuan aplikasi berbasis moodle (Dhika, $\mathrm{H}_{\text {., }}$ Destiawati, F., Surajiyo, S., \& Jaya, M., 2020). Ningrum, M. V. R., \& Rosita, D., 2019). Pemilihan moodle sebagai platform yang banyak digunakan menurut Soraya, S.,
Suherma, L., \& Zawitri, S. (2020). karena moodle memiliki fasilitas pembelajaran yang paling sesuai dengan manajemen pembelajaran konvensioal. Sehingga penggunaanya kemudian dianggap tidak memberikan gap bagi pengguna.

Keunggulan moodle ini juga menarik minat pengembangan aplikasi e-learning di BDK Bandung. Aplikasi ini sangat mendukung kebijakan pelaksanana pelatihan jarak jauh. Sebagai lembaga dengan layanan pelatihan yang pengguna layanannya adalah orang dewasa dengan asumsi bukan termasuk tuan rumah di era internet ini, maka penting untuk memperhatikan aspek kemudahan penggunaan aplikasi e-learning agar tidak terlalu jauh dengan kebiasaan-kebiasaan dalam pola pembelajaran konvensional.

Moodle merupakan akronim dari Modular Object Oriented Dynamic Learning Environment (Rice, 2006). Membangun aplikasi pelatihan jarak jauh berbasis moodle merupakan sebuah proses yang terencana yang menuntut kreatifitas dan pemikiran dari tim pengembang PJJ yang kemudian diterjemahkan kedalam sebuah alur aktifitas bagi widyaiswara, peserta dan admin dengan perannya masing-masing.

Moodle adalah sebuah program LMS (learning management system) tidak berbayar dan open source yang dapat mengubah sebuah media pembelajaran ke dalam bentuk web yang mana moodle ini memungkinkan setiap orang dapat memberikan materi-materi pembelajarannya secara online. Pengembanganya didesain untuk mendukung kerangka konstruksi sosial (social construct) dalam pendidikan.

Moodle termasuk dalam model CAL+CAT (Computer Assisted Learning+Computer Assisted Teaching) yang kemudian disebut dengan LMS (Learning Management System), (Prakoso, 2005). LMS menjadi fasilitas utama dan penting dalam proses pengajaran dan pembelajaran daring. Kumpulan perangkat lunak yang ada diatur sedemikian rupa pada tingkat individu, ruang belajar, maupun institusi. Ciri khas LMS adalah antara pengguna yang merupakan pengajar dan peserta didik, keduanya harus terkoneksi dengan internet saat menggunakan aplikasi ini. 
Berikut ini beberapa aktivitas pembelajaran yang didukung oleh moodle adalah sebagai berikut: 1) Assignment : Dengan aktifitas ini, widyaiswara dapat memberikan tugas dalam bentuk soal-soal, penyusunan makalah, laporan dan sebagainya. Selanjutnya tugas tersebut dikumpul melalui cara upload maupun berupa online text yang sudah disediakan fasilitasnya pada bagian penyampaian tugas. Jenis file yang dapat dikirim misalnya documents, spreadsheets, images, audio and video. Selanjutnya widyaiswara dapat melihat dan menilai tugas yang telah dikirim oleh peserta pelatihan. 2) Attendance : Daftar absensi peserta pelatihan, fitur ini tidak secara langsung terdapat pada moodle, akan tetapi ditambahkan oleh pengembang PJ] sehingga terdaftar dalam aktivitas. 3) Big blue button dan Zoom meeting: merupakan fitur konferensi web yang memungkinkan terjadi komunikasi dua arah secara langsung antara widyaiswara dan peserta pelatihan melalui video, audio dan teks. 4) Chats: Dengan aktivitas ini, setiap peserta dapat berdiskusi secara real-time via web, diskusi secara langsung ini dapat berlangsung antara widyaiswara dengan peserta pelatihan atau antara para peserta pelatihan itu sendiri. 5) Database: Melalui aktifitas ini, widyaiswara dan peserta pelatihan dapat membuat, melihat dan mencari bank data mengenai topik apapun. Format dan struktur data yang dimasukkan hampir tidak terbatas, termasuk gambar, file, URL, nomor, dan text. 6) External tool: Modul alat eksternal, aktivitas memungkinkan peserta pelatihan untuk berinteraksi dengan sumber belajar dan kegiatan di situs web lain. Misalnya, melalui alat eksternal ini, widyaiswara dapat memberikan akses ke jenis kegiatan baru atau bahan pembelajaran dari sumber lainnya bagi peserta pelatihan. Untuk membuat kegiatan alat eksternal, penyedia alat yang mendukung LTI (Learning Tools Interoperability). Widyaiswara dapat menciptakan kegiatan alat eksternal atau menggunakan alat yang sebelumnya telah dikonfigurasi oleh administrator moodle. Kegiatan alat eksternal berbeda dari sumber bahan ajar melalui URL. 7) Feedback : merupakan kegiatan umpan balik yang memungkinkan widyaiswara menciptakan sebuah survei untuk mengumpulkan umpan balik dari para peserta pelatihan menggunakan berbagai jenis pertanyaan termasuk pilihan ganda, ya / tidak atau input teks. 8) Forum mirip dengan chat, forum ini lebih dikenal dengan istilah forum diskusi, merupakan fasilitas untuk melangsungkan sebuah diskusi antar peserta pelatihan maupun antara peserta pelatihan dengan widyaiswara. Peserta pelatihan dan widyaiswara dapat berinteraksi satu sama lain secara real-time. Namun tidak seperti chat, pada forum interaksi yang dilakukan secara asinkron. Setiap peserta yang tergabung dalam forum akan menerima salinan dari setiap kiriman percakapan ke email mereka. 9) Glossary : Pada aktivitas ini, widyaiswara dan peserta pelatihan dapat membuat kumpulan/daftar pengertianpengertian kata, seperti kamus. Data yang dimasukkan dapat berasal dari berbagai format dan secara otomatis dapat dibuat link ke materi lain. 10) Lesson : Lesson ditujukan agar widyaiswara dapat membuat aktifitas yang berisi konten yang menarik dan fleksibel. Lesson terbagi menjadi beberapa halaman dan diakhir setiap halaman biasanya terdapat pertanyaan yang memiliki beberapa jawaban. Jawaban yang dipilih peserta pelatihan akan menentukan halaman mana yang akan diaksesnya, dengan kata lain jika pertanyaan yang diajukan benar maka disediakan bahan ajar selanjutnya untuk dipelajari. 11) Quiz: Pada modul ini, widyaiswara dapat mendesain kumpulan soal, yang berisi multiple choice, true-false, jawaban singkat, atau bentuk lainnya. Pertanyaanpertanyaan tersebut akan tersimpan di bank soal yang dapat dikategorikan dan digunakan ulang. 12) Scrom packages: dengan aktifitas ini widyaiswara dapat membuat paket yang berisi halaman web, grafis, program Javascript, slide presentasi Flash, video, suara dan konten apapun yang dapat dibuka di web browser. Fasilitasi ini juga diintegrasikan kumpulan soal yang bila diperlukan dapat dinilai dan kemudian dimasukkan ke rapor hasil belajar siswa. 13) Survey : Merupakan feedback, quisioner ataupun angket yang dapat digunakan sebagai bahan pembelajaran ataupun kritikan widyaiswara ataupun pelatihan yang diikuti peserta. Sehingga kinerja widyaiswara dan isi dari course dapat diperbaiki diwaktu akan datang. 14) Wiki: fasilitas ini memungkinkan 
peserta pelatihan dan widyaiswara dapat secara kolaboratif menulis dokumen web tanpa mengetahui bahasa html, langsung dari web browser. Hasilnya dapat berupa hasil kreativitas kelas, kelompok ataupun individu. 15) Workshop: peserta pelatihan dapat menyerahkan pekerjaan mereka selama kegiatan. Setiap peserta pelatihan menyerahkan pekerjaan mereka sendiri. Pengajuan dapat terdiri dari teks dan lampiran. Oleh karena itu, penyerahan lokakarya menggabungkan baik teks online dan upload jenis file dari modul assignment.

Sebagai aplikasi yang terbuka dan terus meingkatkan versi terbarunya, moodle saat ini telah berada dalam versi 3.8.0. Versi ini semakin menegaskan keunggulan fitur moodle sebagai aplikasi penyedia LMS. Salah satu keunggulan versi ini adalah adaptif dengan penggunaan pada android. Sehingga para peserta pelatihan dapat mengaksesnya dengan mudah dan nyaman melalui smartphone mereka. Hal ini sesuai dengan prinsip keberterimaan teknologi bahwa sebuah aplikasi akan banyak diterima oleh pengguna jika ia semakin mudah dalam mengoperasikan, nyaman dalam pemakaian dan murah (Rochdianingrum, W. A., Rahayu, R., \& Iswara, 2019).

Berdasarkan uraian tersebut di atas, maka permasalahan dapat dirumuskan sebagai berikut: Bagaimanakah pengembangan sistem pelatihan jarak jauh berbasis moodle di Balai Diklat Keagamaan Bandung? Manfaat teoritis yang diharapkan dari penelitian ini adalah dapat memperkaya pengetahuan dan pengalaman dalam hal pengembangan pelatihanan secara online serta dapat menambah pemahaman tentang pemanfaatan media pembelajaran berbasis web yang bermanfaat dalam proses pelatihan di lembaga pelatihan pada khususnya dan perkembangan dunia pendidikan pada umumnya. Manfaat praktis yang diharapkan dari penelitian ini adalah terciptanya sistem pelatihan jarak jauh berbasis moodle versi terbaru sebagai kegiatan utama perlatihan.

\section{METODE PENELITIAN}

Penelitian ini menggunakan pendekatan Research and Development. Menurut Sri Haryati (2012). Metode penelitian dan pengembangan adalah metode yang digunakan untuk menghasilkan produk tertentu, dan menguji keefektifan produk tersebut. Dalam metode penelitian dan pengembangan terdapat langkah-langkah dari proses yang harus dilakukan. Diantara langkah-langkah yang harus dilakukan adalah mengumpulkan informasi yang dibutuhkan dan mempelajari temuan pada penelitian yang berkaitan dengan produk yang akan dibuat. Setelah mendapat temuan, selanjutnya mengembangkan produk berdasarkan informasi dan temuan, menguji produk setelah jadi dan merevisi produk untuk memperbaiki kekurangan dari hasil uji produk. Setelah dilakukan perbaikan, produk diuji kembali dengan harapan kesempurnaan produk yang dibuat. Langkah terakhir adalah pemeliharaan produk. Dalam penelitian ini, jenis data yang dipaparkan adalah data kualitatif yang diperoleh secara empiris di lapangan mengenai produk website pelatihan jarak jauh berbasis moodle yang dikembangkan.

Peneliti merupakan anggota tim pengembang PJj Balai Diklat Keagamaan Bandung dan admin dari kegiatan pelatihan tersebut. Metode pengumpulan data yang digunakan dalam penelitian ini adalah menggunakan model pengembangan waterfalls. Alasan pemilihan model ini adalah karena model waterfall melakukan pendekatan secara sistematis dan berurutan dalam membangun suatu sistem. Menurut Pressman (2002). Metode waterfall adalah model klasik (Grudin, J., 1992) yang bersifat sistematis, berurutan dalam membangun software. Dalam makna yang sebenarnya model waterfalls adalah "Linier Sequential Model", yaitu suatu pendekatan pengembangan perangkat lunak yang sistematik dan sekuensial. Pendapat yang sama dikemukakan oleh Kisielnicki, J., \& Misiak, A. M. (2017), hal senada juga dikemukakan oleh Lucitasari, D. R., \& Khannan, M. S. A. (2019).. Juga Sudrajat, D., Achdisty, M., Kurniasih, N., Mulyati, S., Purnomo, A., \& Sallu, S. (2019, December). Terdapat lima tahapan 
dalam pengembangan software dengan menggunakan model waterfalls sebagaimana dapat dilihat pada gambar 2

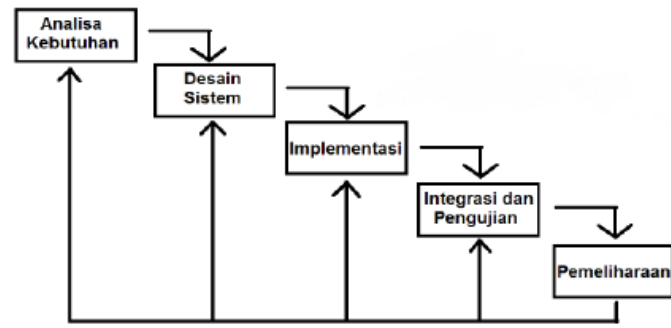

Gambar 2. Model waterfall dalam software engineering

1. Analisis Kebutuhan, pada tahap ini sudah dipastikan bahwa Balai Diklat Keagamaan Bandung sudah memiliki fasilitas yang mendukung untuk membuat sistem pelatihan jarak jauh berbasis moodle. Seperti web server, web host, domain internet, pengembang program dan regulasi yang mendukung.

2. Desain Sistem, pada tahapan ini adalah membuat alur program, isi dan tampilan grafis program. Dokumentasi yang dihasilkan dari tahap desain sistem ini antara lain perancangan Use Case Diagram dan Activity Diagram.

3. Implementasi, desain yang sudah dirancang dituangkan dalam aplikasi moodle.

4. Pengujian sistem, tujuan dari ujicoba sistem ini adalah untuk mengetahui apakah sistem yang telah dibuat sesuai dengan tujuan. Pada pengujian sistem ini menggunakan pengujian perangkat lunak yang menguji fungsionalitas aplikasi yang bertentangan dengan struktur internal atau kerja atau sering disebut dengan black box testing, secara teknis pengujian ini berusaha menemukan kesalahan atau fungsi - fungsi yang tidak benar atau hilang, dan pengujian kepuasan pengguna.

5. Perawatan, tahap ini merupakan tahap terakhir dalam metode waterfall. Sistem dapat diimplementasikan. Pemeliharaan mencakup koreksi dari berbagai error yang tidak ditemukan pada tahapan sebelumnya.

\section{TEMUAN DAN PEMBAHASAN}

\section{Temuan}

Mengembangkan sebuah program aplikasi Komputer harus memperhatikan tiga hal yaitu, perangkat keras (hardware), Perangkat lunak (software) dan unsur manusia / programmer (brainware).

Sarana dan prasarana yang dimiliki Balai Diklat Keagamaan Bandung sudah sangat memadai untuk membuat program PJ] berbasis moodle versi 3.8.0 dengan spesifikasi : PHP 7.1, MariaDB 5.5.31 or MySQL 5.6 or Postgres 9.4 or MSSQL 2012 or Oracle 11.2., sementara spesifikasi dari domain internet milik Balai Diklat Keagamaan Bandung dengan alamat bandungsiemapede.id adalah webserver memory $6 \mathrm{gb}$, processor 4 core multi tasking. php versi 7.4 dan space hardisk $100 \mathrm{gb}$, dengan kata lain spesifikasi minimum yang diminta moodle sudah terpenuhi.

Pemilihan moodle versi 3.8 .0 sebagai aplikasi learning management system yang dikembangkan untuk program PJj di Balai Diklat Keagamaan Bandung adalah sebagai berikut, 1) Sistem jaringan dan juga keamanan yang dapat disetting sendiri, 2) Ruang akses yang dapat dibatasi dengan jaringan yang dibuat. Karena masing masing user memiliki hak akses yang berbeda, 3) Sistem pembelajaran yang dapat disesuaikan dengan kebutuhan user, 4) Fitur yang lengkap untuk sebuah proses pembelajaran jarak jauh, 5) Proses customizing yang relatif mudah dan banyak, 6) Fitur Lesson. Fitur yang menarik dan sengaja di desain untuk mempermudah pengajar dalam beraktifitas membuat konten yang menarik dan fleksible. Sejumlah penelitian mengungkapkan hal yang sama mengenai kelebihan moodle, antara lain dikemukakan oleh Dhika, H., Destiawati, F., Surajiyo, S., \& Jaya, M. (2020). Ningrum, M. V. R., \& Rosita, D. (2019). Pemilihan moodle sebagai platform yang banyak digunakan menurut Soraya, S., Suherma, L., \& Zawitri, S. (2020).

Unsur manusia (brainware) dalam mengembangkan program PJj berbasis moodle di Balai Diklat Keagamaan Bandung dibentuk berdasarkan kompetensi yang dimiliki pegawai. Tujuan dari pembentukan tim pengembang PJJ Balai Diklat Keagamaan Bandung dari lingkungan pegawai sendiri adalah agar 
program yang dibuat sesuai dengan karakteristik proses pembelajaran di lingkungan pelatihan. Para pegawai yang terlibat dalam tim pengembang PJ] sudah sangat memahami alur serta detail pelaksanaan sebuah pelatihan, sehingga tinggal menerjemahkannya kedalam aplikasi moodle.

Tim pengembang PJj Balai Diklat Keagamaan Bandung pada tahap awal proses pengembangan membuat desain sistem dengan tujuan menciptakan gambaran tentang apa yang akan dikerjakan dan bagaimana tampilannya. Dokumentasi yang dihasilkan dari tahapan desain sistem ini salah satunya adalah perancangan use case diagram dan activity diagram, sebagaimana dapat dilihat dari gambar 3 .

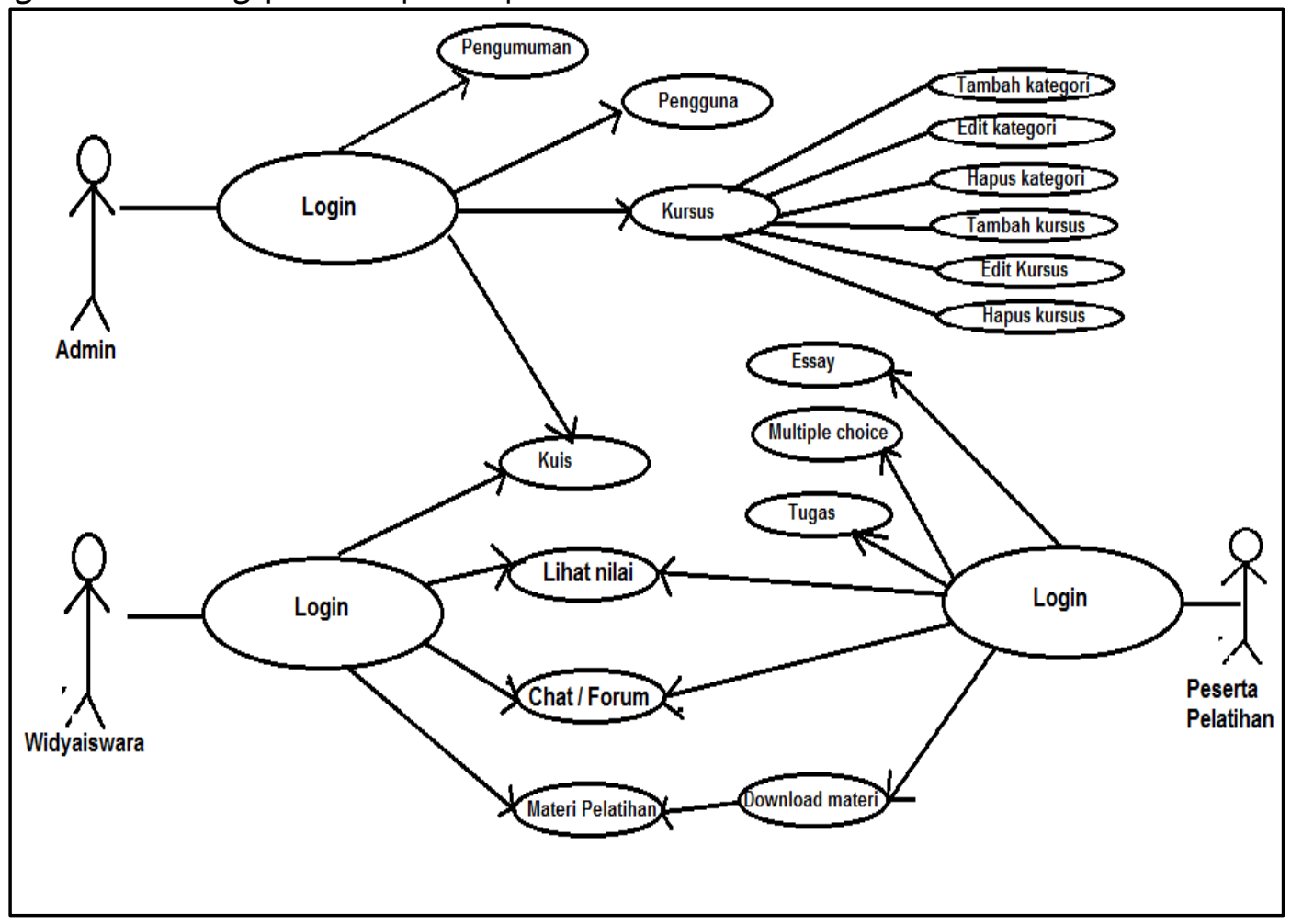

Gambar 3. Use Case Diagram Sistem yang Berjalan

Dalam use case diagram, terdapat empat user yang terlibat dalam kegiatan, diantaranya adalah administrator, panitia penyelenggara, widyaiswara dan peserta pelatihan. Pada use case, admin dapat mengelola semua menu yang ada pada aplikasi PJj berbasis moodle. Dari mulai pengumuman, data widyaiswara, data peserta, mengelola peran user, kelas pelatihan, data mata pelatihan dan mengelola semua aktifitas lainnya. Sedangkan pada user widyaiswara, bisa aktifitas, data mata pelatihan dan aktifitas pembelajaran. Pada user peserta dapat mengikuti materi pelatihan, download dan upload tugas, mengisi daftar hadir, mengikuti ujian atau kuis, forum diskusi, chat, dan melihat nilai.

Pada halaman depan aplikasi PJj Balai Diklat Keagamaan Bandung ini dapat dilihat pada Gambar 3 Ada beberapa menu yang tampil yaitu group menu yang terdiri dari Home, About, Course, Guide, News, Statistic dan Pengaturan Bahasa. Menu tersebut merupakan menu standar tampilan website yang berisi identitas, petunjuk dan pengaturan bahasa.

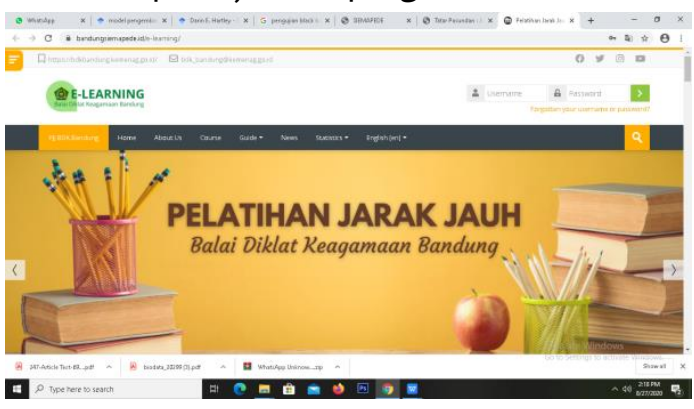

Gambar 4. Halaman depan PJj Balai Diklat Keagamaan Bandung 
Halaman awal (Home page) PJJ Balai Diklat Keagamaan Bandung juga terdapat halaman login yang berfungsi sebagai pintu masuk bagi semua user yang terlibat dalam kegiatan pelatihan jarak jauh baik itu admin, widyaiswara maupun peserta pelatihan.

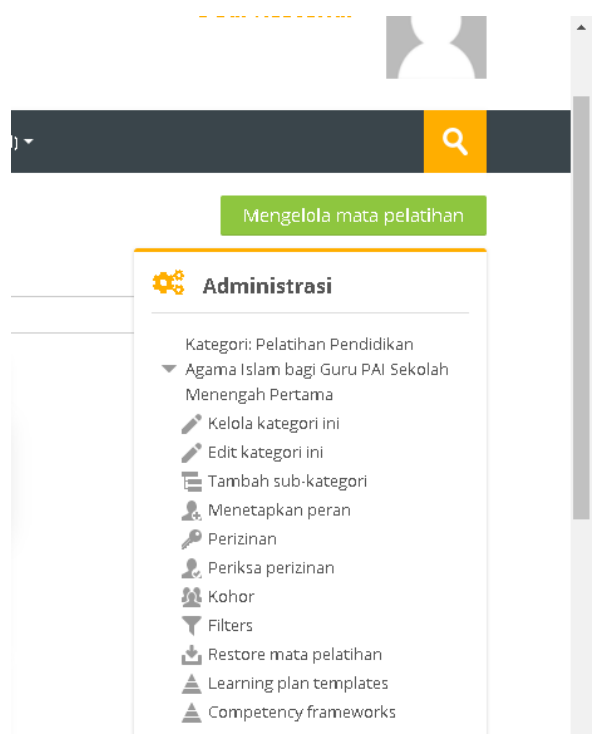

Gambar 5. Halaman administrator

Halaman administrator adalah pusat kendali manajemen sistem secara keseluruhan. Admin bisa membuat account widyaiswara dan account peserta, menentukan peran dan mengelola seluruh sumber daya yang terdapat dalam aplikasi PJJ Balai Diklat Keagamaan Bandung.

Tahapan selanjutnya ketika program PJJ Balai Diklat Keagamaan Bandung berbasis moodle sudah selesai dibangun, tim pengembang melakukan pengujian dengan system black box. Black Box Testing adalah cara pengujian dengan menjalankan atau mengeksekusi model, kemudian diamati apakah hasil dari model itu sesuai dengan proses bisnis yang diinginkan. Aplikasi PJJ dijalankan dengan menggunakan web browser. Pengujian ini dilakukan untuk mengetahui apakah fitur yang terdapat pada PJJ berjalan dengan baik sesuai dengan fungsinya. Tahapan pengujian fungsional ini dilakukan dengan cara mengakses atau menjalankan fitur yang terdapat dalam apliksi PJJ.

Tabel 1 Uji Black Box Halaman Admin

\begin{tabular}{|c|c|c|c|}
\hline $\begin{array}{l}\text { Test } \\
\text { case }\end{array}$ & Prosedur & $\begin{array}{l}\text { Hasil yang } \\
\text { diharapkan }\end{array}$ & Hasil \\
\hline $\begin{array}{l}\text { Login } \\
\text { admin }\end{array}$ & $\begin{array}{l}\text { Memasukan } \\
\text { username } \\
\text { dan } \\
\text { password }\end{array}$ & $\begin{array}{l}\text { Berhasil masuk } \\
\text { ke } \\
\text { halaman admin }\end{array}$ & $\begin{array}{l}\text { Berhasi } \\
1\end{array}$ \\
\hline $\begin{array}{l}\text { Tambah } \\
\text { penggu } \\
\text { na }\end{array}$ & $\begin{array}{l}\text { Pilih menu } \\
\text { Site } \\
\text { Administrat } \\
\text { ion, Users, } \\
\text { Add } \\
\text { New User }\end{array}$ & $\begin{array}{ll}\text { Data } & \text { user } \\
\text { berhasil } & \\
\text { ditambah } & \end{array}$ & $\begin{array}{l}\text { Berhasi } \\
1\end{array}$ \\
\hline $\begin{array}{l}\text { Edit } \\
\text { penggu } \\
\text { na }\end{array}$ & $\begin{array}{l}\text { Pilih menu } \\
\text { Site } \\
\text { Administrat } \\
\text { ion, User, } \\
\text { Browse List } \\
\text { of Users }\end{array}$ & $\begin{array}{ll}\text { Data } & \text { user } \\
\text { berhasil } & \\
\text { di rubah } & \end{array}$ & $\begin{array}{l}\text { Berhasi } \\
1\end{array}$ \\
\hline $\begin{array}{l}\text { Hapus } \\
\text { penggu } \\
\text { na }\end{array}$ & $\begin{array}{l}\text { Pilih menu } \\
\text { Site } \\
\text { Administrat } \\
\text { ion, User, } \\
\text { Browse List } \\
\text { of Users }\end{array}$ & $\begin{array}{l}\text { Data user } \\
\text { berhasil }\end{array}$ & $\begin{array}{l}\text { Berhasi } \\
1\end{array}$ \\
\hline $\begin{array}{l}\text { Add } \\
\text { Categor } \\
y \\
\text { (Kelas) }\end{array}$ & $\begin{array}{l}\text { Pilih menu } \\
\text { Site } \\
\text { Administrat } \\
\text { ion, } \\
\text { Courses, } \\
\text { Manage } \\
\text { Courses and } \\
\text { Categories }\end{array}$ & $\begin{array}{l}\text { Data Category } \\
\text { (Kelas) di buat }\end{array}$ & $\begin{array}{l}\text { Berhasi } \\
1\end{array}$ \\
\hline $\begin{array}{l}\text { Edit } \\
\text { Categor } \\
y \\
\text { (Kelas) }\end{array}$ & $\begin{array}{l}\text { Pilih menu } \\
\text { Site } \\
\text { Administrat } \\
\text { ion, } \\
\text { Courses, } \\
\text { Manage } \\
\text { Courses and } \\
\text { Categories }\end{array}$ & $\begin{array}{l}\text { Data Category } \\
\text { (Kelas) di buat }\end{array}$ & $\begin{array}{l}\text { Berhasi } \\
1\end{array}$ \\
\hline $\begin{array}{l}\text { Delete } \\
\text { Categor } \\
y \\
\text { (Kelas) }\end{array}$ & $\begin{array}{l}\text { Pilih menu } \\
\text { Site } \\
\text { Administras } \\
\text { i, Courses, } \\
\text { Manage } \\
\text { Courses and } \\
\text { Categories }\end{array}$ & $\begin{array}{l}\text { Data Category } \\
\text { (Kelas) di } \\
\text { hapus }\end{array}$ & $\begin{array}{l}\text { Berhasi } \\
1\end{array}$ \\
\hline $\begin{array}{l}\text { Test } \\
\text { case }\end{array}$ & Prosedur & $\begin{array}{l}\text { Hasil yang } \\
\text { diharapkan }\end{array}$ & Hasil \\
\hline $\begin{array}{l}\text { Membua } \\
\mathrm{t} \\
\text { Course }\end{array}$ & $\begin{array}{l}\text { Pilih menu } \\
\text { Site } \\
\text { Administrat } \\
\text { ion, } \\
\text { Courses, }\end{array}$ & $\begin{array}{l}\text { Data Courses } \\
\text { (Mapel) di buat }\end{array}$ & $\begin{array}{l}\text { Berha } \\
\text { sil }\end{array}$ \\
\hline
\end{tabular}




\begin{tabular}{|c|c|c|c|}
\hline & $\begin{array}{l}\text { Manage } \\
\text { Courses and } \\
\text { Categories }\end{array}$ & & \\
\hline $\begin{array}{l}\text { Edit } \\
\text { Course }\end{array}$ & $\begin{array}{l}\text { Pilih menu } \\
\text { Site } \\
\text { Administrat } \\
\text { ion, } \\
\text { Courses, } \\
\text { Manage } \\
\text { Courses and } \\
\text { Categories }\end{array}$ & $\begin{array}{l}\text { Data Category } \\
\text { (Mapel) di } \\
\text { rubah }\end{array}$ & $\begin{array}{l}\text { Berha } \\
\text { sil }\end{array}$ \\
\hline $\begin{array}{l}\text { Delete } \\
\text { Course }\end{array}$ & $\begin{array}{l}\text { Pilih menu } \\
\text { Site } \\
\text { Administrat } \\
\text { ion, } \\
\text { Courses, } \\
\text { Manage } \\
\text { Courses and } \\
\text { Categories }\end{array}$ & $\begin{array}{l}\text { Data Category } \\
\text { (Mapel) di } \\
\text { hapus }\end{array}$ & $\begin{array}{l}\text { Berha } \\
\text { sil }\end{array}$ \\
\hline $\begin{array}{l}\text { Add } \\
\text { Kuis/So } \\
\text { al }\end{array}$ & $\begin{array}{l}\text { Pilih menu } \\
\text { Site } \\
\text { Administrat } \\
\text { ion, } \\
\text { Courses, } \\
\text { Manage } \\
\text { Courses and } \\
\text { Categories, } \\
\text { Nama } \\
\text { Mapel, add } \\
\text { an activity } \\
\text { or } \\
\text { resources, } \\
\text { quiz }\end{array}$ & $\begin{array}{l}\text { Data Kuis } \\
\text { Berhasil di } \\
\text { buat }\end{array}$ & $\begin{array}{l}\text { Berha } \\
\text { sil }\end{array}$ \\
\hline $\begin{array}{l}\text { Edit } \\
\text { Kuis/So } \\
\text { al }\end{array}$ & $\begin{array}{l}\text { Pilih menu } \\
\text { Site } \\
\text { Administrat } \\
\text { ion, } \\
\text { Courses, } \\
\text { Manage } \\
\text { Courses and } \\
\text { Categories, } \\
\text { Nama } \\
\text { mapel, } \\
\text { nama quiz, } \\
\text { edit quiz }\end{array}$ & $\begin{array}{l}\text { Data Kuis/Soal } \\
\text { berubah }\end{array}$ & $\begin{array}{l}\text { Berha } \\
\text { sil }\end{array}$ \\
\hline $\begin{array}{l}\text { Delete } \\
\text { Kuis/So } \\
\text { al }\end{array}$ & $\begin{array}{l}\text { Pilih menu } \\
\text { Site } \\
\text { Administrasi } \\
\text { 'Courses, } \\
\text { Manage } \\
\text { Courses and } \\
\text { Categories, } \\
\text { Nama } \\
\text { Mapel, } \\
\text { nama quiz, } \\
\text { delete }\end{array}$ & $\begin{array}{l}\text { Data Kuis/Soal } \\
\text { terhapus }\end{array}$ & $\begin{array}{l}\text { Berha } \\
\text { sil }\end{array}$ \\
\hline
\end{tabular}

\begin{tabular}{l|l|l|l}
\hline $\begin{array}{l}\text { Upload } \\
\text { Materi }\end{array}$ & $\begin{array}{l}\text { Pilih mata } \\
\text { pelajaran, } \\
\text { Add an } \\
\text { activity or } \\
\text { resources, } \\
\text { file }\end{array}$ & $\begin{array}{l}\text { Materi bisa di } \\
\text { upload }\end{array}$ & $\begin{array}{l}\text { Berha } \\
\text { sil }\end{array}$ \\
\hline Edit & $\begin{array}{l}\text { Pilih mata } \\
\text { pelajaran }\end{array}$ & $\begin{array}{l}\text { Materi bisa di } \\
\text { ubah }\end{array}$ & $\begin{array}{l}\text { Berha } \\
\text { sil }\end{array}$ \\
\hline Hapus & $\begin{array}{l}\text { Pilih mata } \\
\text { pelajaran, } \\
\text { Add an } \\
\text { Mativity or } \\
\text { resources, } \\
\text { file }\end{array}$ & $\begin{array}{l}\text { Materi bisa di } \\
\text { hapus }\end{array}$ & $\begin{array}{l}\text { Berha } \\
\text { sil }\end{array}$ \\
\hline
\end{tabular}

Tabel 2 Uji Black Box Halaman Widyaiswara

\begin{tabular}{|c|c|c|c|}
\hline $\begin{array}{l}\text { Test } \\
\text { case }\end{array}$ & Prosedur & $\begin{array}{l}\text { Hasil yang } \\
\text { diharapkan }\end{array}$ & Hasil \\
\hline $\begin{array}{l}\text { Login } \\
\text { widyais } \\
\text { wara }\end{array}$ & $\begin{array}{l}\text { Memasukan } \\
\text { username } \\
\text { dan } \\
\text { password }\end{array}$ & $\begin{array}{l}\text { Berhasil masuk } \\
\text { kehalaman } \\
\text { widyaiswara }\end{array}$ & Berhasil \\
\hline $\begin{array}{l}\text { Membua } \\
t \\
\text { berbaga } \\
\mathrm{i} \text { jenis } \\
\text { kuis }\end{array}$ & $\begin{array}{l}\text { Masuk course } \\
\text {-turn editing } \\
\text { on - add an } \\
\text { activity or } \\
\text { resource - } \\
\text { quiz - create } \\
\text { quiz }\end{array}$ & $\begin{array}{l}\text { Berhasil } \\
\text { membuat kuis }\end{array}$ & Berhasil \\
\hline $\begin{array}{l}\text { Melihat } \\
\text { nilai } \\
\text { peserta }\end{array}$ & $\begin{array}{l}\text { Masuk course } \\
\text { - } \\
\text { Administrati } \\
\text { on - Site } \\
\text { administrati } \\
\text { on - - grades }\end{array}$ & $\begin{array}{l}\text { Berhasil } \\
\text { melihat nilai } \\
\text { seluruh } \\
\text { peserta }\end{array}$ & Berhasil \\
\hline $\begin{array}{l}\text { Membua } \\
\mathrm{t} \text { chat } \\
\text { room / } \\
\text { forums }\end{array}$ & $\begin{array}{l}\text { Masuk course } \\
\text {-turn editing } \\
\text { on - add an } \\
\text { activity or } \\
\text { resource - } \\
\text { chat / forum } \\
\text { - create chat } \\
\text { / forum }\end{array}$ & $\begin{array}{l}\text { Berhasil } \\
\text { membuat chat } \\
\text { room / forum }\end{array}$ & Berhasil \\
\hline $\begin{array}{l}\text { Membua } \\
\mathrm{t} \text { materi } \\
\text { pelatiha } \\
\mathrm{n}\end{array}$ & $\begin{array}{l}\text { Masuk course } \\
\text {-turn editing } \\
\text { on - add an } \\
\text { activity or } \\
\text { resource - } \\
\text { Assigment/fi } \\
\text { le/book/fold } \\
\text { er-create }\end{array}$ & $\begin{array}{l}\text { Berhasil } \\
\text { membuat } \\
\text { materi }\end{array}$ & Berhasil \\
\hline
\end{tabular}

Tabel 3 Uji Black Box Halaman Peserta Pelatihan 


\begin{tabular}{l|l|l|l}
\hline \multicolumn{1}{c|}{$\begin{array}{l}\text { Test } \\
\text { case }\end{array}$} & Prosedur & \multicolumn{1}{|c}{$\begin{array}{l}\text { Hasil yang } \\
\text { diharapkan }\end{array}$} & Hasil \\
\hline $\begin{array}{l}\text { Login } \\
\text { peserta }\end{array}$ & $\begin{array}{l}\text { Masukan } \\
\text { username } \\
\text { dan } \\
\text { password }\end{array}$ & $\begin{array}{l}\text { Berhasil masuk } \\
\text { ke halaman } \\
\text { peserta }\end{array}$ & $\begin{array}{l}\text { Berhas } \\
\text { il }\end{array}$ \\
\hline $\begin{array}{l}\text { Mengerj } \\
\text { akan } \\
\text { kuis }\end{array}$ & $\begin{array}{l}\text { Course - } \\
\text { mata diklat }\end{array}$ & $\begin{array}{l}\text { Berhasil } \\
\text { mengerjakan } \\
\text { mengerjaka } \\
\text { n quiz }\end{array}$ & $\begin{array}{l}\text { Berhas } \\
\text { il }\end{array}$ \\
\hline Melihat & $\begin{array}{l}\text { Course - } \\
\text { mata diklat }\end{array}$ & $\begin{array}{l}\text { Berhasil melihat } \\
\text { nilai }\end{array}$ & Berhas \\
& - & il \\
& $\begin{array}{l}\text { button } \text { user } \\
\text { grades }\end{array}$ & & \\
\hline
\end{tabular}

\section{Pembahasan}

Penelitian ini menghasilkan sebuah portal e-learning dengan nama e-learning Balai Diklat Keagamaan Bandung dan dapat diakses secara online pada alamat https://bandungsiemapede.id/e-learning. Pengembangan pelatihan jarak jauh di Balai Diklat Keagamaan Bandung mengacu pada teori yang dikemukakan oleh Haughey (1998). Teori ini menyebutkan ada tiga kemungkinan dalam pengembangan sistem pembelajaran berbasis internet, yaitu 1) Web course adalah penggunaan internet untuk keperluan pendidikan, yang mana peserta didik dan pengajar sepenuhnya terpisah dan tidak diperlukan adanya tatap muka. Seluruh bahan ajar, diskusi, konsultasi, penugasan, latihan, ujian, dan kegiatan pembelajaran lainnya sepenuhnya disampaikan melalui internet. Dengan kata lain model ini menggunakan sistem jarak jauh 2) Web centric course adalah penggunaan internet yang memadukan antara belajar jarak jauh dan tatap muka (konvensional). Sebagian materi disampaikan melalui internet, dan sebagian lagi melalui tatap muka. Fungsinya saling melengkapi. 3) Web enchanced course adalah pemanfaatan internet untuk menunjang peningkatan kualitas pembelajaran yang dilakukan di kelas. Fungsi internet adalah untuk memberikan pengayaan dan komunikasi antara peserta didik dengan pengajar, sesama peserta didik, anggota kelompok, atau peserta didik dengan nara sumber lain.
Pelatihan jarak jauh berbasis moodle dikembangkan seolah-olah peserta pelatihan belajar secara konvensional, hanya saja dipindahkan ke dalam sistem digital melalui internet. Oleh karena itu e-learning yang dalam hal ini adalah pelatihan jarak jauh sudah mengadaptasi unsur-unsur yang biasa dilakukan dalam sistem pelatihan konvensional misalnya dimulai dari perumusan tujuan yang operasional dan dapat diukur, ada apersepsi atau pre test, membangkitkan motivasi, menggunakan bahasa yang komunikatif, uraian materi yang jelas, contoh-contoh konkrit, problem solving, tanya jawab, diskusi, post test, sampai penugasan dan kegiatan tindak lanjutnya.

Kondisi ini seperti temuan Silahuddin, S (2015) yang melihat pengembangan platform e-learning yang bukan hanya mengakomodir sisi anggaran, melainkan juga sisi psikologis pengguna atau pebelajar. Dari sisi yang terakhir ini, pengembangan sarana pembelajaran jarak jauh menjadi bukan barang eksklusif dan berjarak. Program ini akan mampu menjadi jalan keluar dan menjawab keterbatasan pembelajaran secara interface sebagaimana biasanya dilaksanakan.

Tahap pelaksanaan dalam pengguanan moodle pelatihan jarak jauh di Balai Diklat Keagamaan Bandung, pada tahun 2020 menyerap 450 peserta dari Sembilan angkatan. Dari segi daya tampung program sesungguhnya bisa jauh lebih banyak lagi. Namun demikian angka tersebut merupakan penjabaran dari rencana program pelatihan dalam anggaran di Balai Diklat Keagamaan Bandung. Artinya, aplikasi ini dari sisi penggunaan dan kebermanfaatan dapat menjawab kebutuhan pengembangan diklat ke depan.

Paket pelatihan e-learning Balai Diklat Keagamaan telah memenuhi syarat sebuah paket konten pembelajaran yang dibangun berdasarkan standarisasi SCORM (Shareable Content Object Reference Model). standarisasi ini merupakan standar pendistribusian paket $e$ learning berbasis web dengan mengacu pada interoperability, accesibility dan reuseability (Rice, 2006).

Penerapan standarisasi tersebut dapat dilihat dari: 
1. Accesibility, portal e-learning Balai Diklat Keagamaan Bandung dapat diakses secara online sehingga setiap komponen yang ada pada Aggregation package dapat ditemukan siapa saja.

2. Adaptability, materi pada content Aggregation package telah disesuaikan dengan kurikulum yang berlaku dari pusdiklat tenaga teknis pendidikan dan keagamaan Kementerian Agama.

3. Afforadability, dengan sekali memproduksi content Aggregation package dapat digunakan secara berulang ulang tanpa harus diproduksi lagi.

4. Durability, setiap pembaharuan dapat diikuti tanpa harus melakukan konfigurasi dan menyimpan ulang.

5. Interoperability, repository yang telah dibuat dapat digunakan sebagai media untuk menyimpan dan mengambil semua konten dan bisa digunakan kembali.

6. Reusability, susunan materi yang telah dibuat dapat diatur ulang sesuai dengan kebutuhan tanpa merubah materi yang sudah ada sebelumnya.

Portal e-learning Balai Diklat Keagamaan Bandung dilihat dari aspek Accesibility, berdasarkan pengalaman dalam pelaskanaan pelatihan jarak jauh tahun 2020 menunjukkan respon yang positif. Seluruh peserta dan calon peserta dapat mengakses portal dengan baik. Hal ini sesuai dengan hasil pengujian awal yang menunjukkan ketebacaan portal secara online dan berdaya jangkau yang luas. Hasil dari pembukaan program pelatihan jarak jauh ini dapat diakses oleh calon peserta sebanyak 2016 orang. Jumlah tersebut kemudian dilakukan seleksi secara online pula dan menghasilkan peserta pelatihan 450 orang.

Dilihat dari aspek Adaptability, portal inipun menunjukkan kinerja yang baik. Artinya kebutuhan kurikulum yang telah dikembangkan oleh Pusdiklat, portal dapat memenuhinya. Pengembangan portal e-learning dapat disesuaikan dengan kurikulum dan sebaliknya pengguna juga dapat dengan mudah untuk mengakses dan menggunakannya dengan cara mempelajari aplikasi secara singkat. Kemampuan penyesuaian antara portal dengan kebutuhan baik dari aspek program maupun penggunaan ini secara nyata responnya terlihat dari aktifitas peserta selama mengikuti pelatihan jarak jauh. Dengan demikian, portal berbasis moodle ini seperti yang ditemukan oleh Samala, A. D., Fajri, B. R., \& Ranuharja, F. (2019), Wicaksana, E. (2020) yang melihat keefektifan pemebelajaran daring terutama di masa pandemi.

Seperti diungkapkan Rice (2006), asepk afforadability merupakan point penting dalam pengembangan portal e-learning. Aplikasi pelatihan jarak jauh di Balai Diklat Keagamaan Bandung telah membuktikan hal tersebut yaitu dari Sembilan angkatan pelatihan yang pesertanya adalah para guru, yang berarti memiliki beberapa kemiripan dan pengulangan beberapa informasi dasar dalam pelatihan, platform ini dapat menyediakannya. Konten pelatihan dapat disajikan dalam waktu yang lebih singkat karena proses input materi dilakukan di awal dan dapat diduplikasi untuk pelatihan serupa. Pola ini memudahkan bagi pengelola pelatihan dalam memberikan layanan pelatihan yang optimal kepada peserta (Budhianto, 2020).

Berangkat dari pengalaman Samala (2019), Budhianto (2020), Wicaksana (2020) di atas, sejalan dengan apa yang dialami dalam penggunaan portal e-learning berbasis moodle di Balai Diklat Keagamaan Bandung. Kemampuannya dalam menyimpan informasi yang telah dimasukan dalam repository menjadikan portal ini memiliki keunggulan dalam aspek penataan ulang setiap materi yang telah disajikan untuk dipergunakan kembali. Prinsip Interoperability dan Reusability yang disyaratkan Rice (2006) dapat dikonfirmasi dengan baik selama pelaksanaan pelatihan jarak jauh pada tahun 2020. Lain dari itu, pembaruan informasi (Durability) dalam platform $e$ learning yang dikembangkan di Balai Diklat Keagamaan Bandung ini mudah untuk dilakukan. Dari Sembilan angkatan pelatihan jarak jauh untuk tenaga guru, pada periode berikutnya juga dilaksanakan pelatihan bagi tenaga pengawas dengan menggunakan platform yang sama. Perpindahan dan perubahan jenis pelatihan ini tentu berbeda dari aspek kebutuhan peserta yang juga tuntutan 
kurikulum pelatihan yang berbeda pula. Namun semua itu tidak menjadi kendala saat harus dilakukan pembaruan informasi meski dalam platform yang sama. Kondisi ini menjadikan pilihan moodle untuk menjadi aplikasi pengembangan e-learning sebagai sarana pelatihan jarak jauh menjadi niscaya dengan hasil yang optimal. Kondisi-kondisi tersebut pada dasarnya merupakan bagian dari pengakuan pengguna terhadap layanan aplikasi moodle seperti yang juga telah ditemukan oleh riset-riset lain (Samala, 2019; Budhianto, 2020; Pancawati, R., \& Siswandi, G., 2020; Wicaksana, E., 2020).

\section{PENUTUP}

\section{Simpulan}

Riset ini menyimpulkan bahwa:

a. Penelitian pengembangan aplikasi $e$ learning untuk kegiatan Pelatihan Jarak Jauh di Balai Diklat Keagamaan Bandung menghasilkan portal dengan nama $e$ learning Balai Diklat Keagaman Bandung yang dapat diakses secara online melalui alamat

https://bandungsiemapede.id/elearning

b. Paket konten e-learning yang disusun untuk pelatihan telah memenuhi standarisasi SCORM meliputi interoperability, accesibility dan reuseability.

c. Pengembangan e-learning Balai Diklat Keagamaan Bandung memenuhi Teori Haughey yang menyebutkan ada tiga kemungkinan dalam pengembangan sistem pembelajaran berbasis internet, yaitu web course, web centric course dan web enhanced course.

\section{Rekomendasi}

Penelitian ini baru sampai pada tahap pengembangan e-learning dan penyusunan paket konten, sehingga perlu diadakan penelitian lebih lanjut mengenai penilaian produk dari segi tampilan dan layout website, dan interaktifitas. 


\section{DAFTAR PUSTAKA}

Al-araibi, A. A. M., Naz'ri bin Mahrin, M., Yusoff, R. C. M., \& Chuprat, S. B. (2019). A model for technological aspect of e-learning readiness in higher education. Education and Information Technologies, 24(2), 1395-1431.

Borg,Walter\&Meredith D.Gall. (1983). Educational Research. 4th ed, Logman Inc.

Budhianto, B. (2020). Analisis perkembangan dan faktor yang mempengaruhi keberhasilan Pembelajaran Daring (E-Learning).

Chang, V. (2016). Review and discussion: E-learning for academia and industry. International Journal of Information Management, 36(3), 476-485.

Dhika, H., Destiawati, F., Surajiyo, S., \& Jaya, M. (2020, July). Implementasi Learning Management System Dalam Media Pembelajaran Menggunakan Moodle. In Prosiding Seminar Nasional Riset Information Science (SENARIS) (Vol. 2, pp. 228-234).

Grudin, J. (1992). Utility and usability: research issues and development contexts. Interacting with computers, $4(2), 209-217$.

Haryati, Sri. 2012. Research And Development (R\&D) Sebagai Salah Satu Model Penelitian Dalam Bidang Pendidikan.

Haughey, M., T Anderson, T Anderson. (1998). The pedagogy of the Internet -Chenelière/McGraw-Hill.

Kisielnicki, J., \& Misiak, A. M. (2017). Effectiveness of agile compared to waterfall implementation methods in IT projects: Analysis based on business intelligence projects. Foundations of Management, 9(1), 273-286.

Lucitasari, D. R., \& Khannan, M. S. A. (2019). Designing Mobile Alumni Tracer Study System Using Waterfall Method: an Android Based. International Journal of Computer Networks and Communications Security, 7(9), 196-202.

Ningrum, M. V. R., \& Rosita, D. (2019). PENGEMBANGAN E-LEARNING BERBASIS MOODLE DI FAKULTAS KEGURUAN DAN ILMU PENDIDIKAN UNIVERSITAS MULAWARMAN. Sebatik, 23(2), 517-521.

Pancawati, R., \& Siswandi, G. (2020). THE DEVELOPMENT OF ONLINE TUTORIAL MOODLE TO INCREASE THE EFFECTIVENESS OF LECTURES DURING PANDEMIC COVID-19. BALANGA: Jurnal Pendidikan Teknologi dan Kejuruan, 8(2), 75-80.

Pressman, Roger S. (2002). Rekayasa Perangkat Lunak: Pendekatan Praktisi. Komputer - Perangkat Lunak, Andi Publisher.

Rice, W. H. (2006). Moodle: E-learning Course Development: a Complete Guide to Successful Learning Using Moodle.-Includes Index. Packt Pub.

Rochdianingrum, W. A., Rahayu, R., \& Iswara, U. S. (2019). Keterkaitan antara Kenyamanan dan Kemudahan Bertransaksi pada Intensitas Penggunaan Layanan Aplikasi GRAB. In Prosiding Seminar Nasional Multi Disiplin Ilmu dan Call for Papers Unisbank (SENDI_U) Ke 5 Tahun 2019 (pp. 382-389). Universitas STIKUBANK, Semarang.

Samala, A. D., Fajri, B. R., \& Ranuharja, F. (2019). Desain dan Implementasi Media Pembelajaran Berbasis Mobile Learning Menggunakan Moodle Mobile App. Jurnal Teknologi Informasi Dan Pendidikan, 12(2), 13-20.

Silahuddin, S. (2015). Penerapan E-Learning dalam Inovasi Pendidikan. CIRCUIT: Jurnal Ilmiah Pendidikan Teknik Elektro, 1(1).

Soraya, S., Suherma, L., \& Zawitri, S. (2020). Pemanfaatan E-Learning berbasis Moodle dalam Meningkatkan Motivasi dan Hasil Belajar. Eksos, 16(1), 72-83. 
Sudrajat, D., Achdisty, M., Kurniasih, N., Mulyati, S., Purnomo, A., \& Sallu, S. (2019, December). The Implementation of Innovation in Educational Technology to Improve The Quality of Website Learning in Industrial Revolution Era 4.0 Using Waterfall Method. In Journal of Physics: Conference Series (Vol. 1364, No. 1, p. 012044). IOP Publishing.

Tvenge, N., \& Martinsen, K. (2018). Integration of digital learning in industry 4.0. Procedia manufacturing, 23, 261-266.

Wicaksana, E. (2020). Efektifitas Pembelajaran Menggunakan Moodle Terhadap Motivasi Dan Minat Bakat Peserta Didik Di Tengah Pandemi Covid-19. EduTeach: Jurnal Edukasi Dan Teknologi Pembelajaran, 1(2), 117124. 